\title{
Association of Anti- $\beta 1$ and Anti-M2 Antibodies with Autonomic Nervous System Modulation in Patients with Chronic Chagas Cardiomyopathy
}

Delma Maria Cunha, ${ }^{1 \oplus}$ Pedro Cunha Tzirulnik, ${ }^{\circledR}$ Patricia Cristina dos Santos Costa, ${ }^{2,3}$ Danton Machado Cunha, ${ }^{\oplus}$ Ademir Batista da Cunha ${ }^{4}$

Instituto Nacional de Cardiologia, ${ }^{1}$ Rio de Janeiro, RJ - Brazil

Universidade Federal do Estado do Rio de Janeiro, ${ }^{2}$ Rio de Janeiro, RJ - Brazil

Universidade Federal do Rio de Janeiro, ${ }^{3}$ Rio de Janeiro, $R J$ - Brazil

Universidade Federal Fluminense - Hospital Universitário Antônio Pedro, ${ }^{4}$ Niterói, $R J$ - Brazil

\section{Abstract}

Background: Different immune mechanisms of myocardial damage involved in the pathophysiology of Chagas disease coexist with high titers of autoantibodies induced by T. cruzi. There are few studies in the literature about the adaptive role of anti- $\beta 1$ and anti-M2 antibodies in chronic Chagas cardiomyopathy (CCC).

Objectives: To evaluate the association between anti- $\beta 1$ and anti-M2 antibodies with heart rate variability (HRV) parameters on $24 \mathrm{~h}$ Holter monitoring and the rate-pressure product (RPP) on cardiopulmonary exercise testing (CPET).

Methods: Anti- $\beta 1$ and anti-M2 antibody titers were measured by enzyme-linked immunosorbent assay (ELISA) in 64 patients affected by CCC. Analysis of HRV was performed through the time-domain indices NNs, mean NN, SDNN, SDANN, SDNN index, NNNs, RMSSD, and pNN50. Spearman's correlation coefficient was used to assess the association between antibody titers and numerical variables. The Mann-Whitney test was used for comparison between two groups. Multiple linear regression was used to identify independent variables capable of explaining anti- $\beta 1$ and anti-M2 antibody titers at the $5 \%$ significance level.

Results: On 24h Holter, during the period of greatest parasympathetic activation (2:00-6:00 a.m.), an inverse association was found between anti- $\beta 1$ titers and $\operatorname{SDNN}\left(\mathrm{r}_{\mathrm{s}}=-0.13, p=0.041, \mathrm{n}=43\right)$, as well as a direct association between anti-M2 titers and SDANN $\left(r_{s}=0.317, p=0.039, \mathrm{n}=43\right)$. Regarding CPET variables, anti- $\beta 1$ titers were directly associated with RPP ( $\left.r_{s}=0.371, p=0.005, n=56\right)$. The subgroup of patients with a normal chronotropic response showed higher anti- $\beta 1$ titers than the subgroup with an impaired response $(p=0.023)$. RPP was an independent explanatory variable for anti- $\beta 1$ titers, although with a low coefficient of determination $\left(\mathrm{R}^{2}=0.147\right)$.

Conclusion: The findings of this study suggest that, in patients with CCC, anti- $\beta 1$ and anti-M2 antibodies may affect HRV parameters. RPP was directly associated with higher anti- $\beta 1$ titers.

Keywords: Chagas Disease/ physiopathology; Antibodies, Bispecific; Anti-B1, Anti-M2; Antibody, Formation; Autonomic Nervous System.

\section{Introduction}

Chagas disease (CD) is one of the four leading causes of death from infectious and parasitic diseases in Brazil. ${ }^{1-3}$ The elucidation of its pathogenesis was marked by pivotal studies that evaluated cross-reactivity between the ribosomal P protein of Trypanosoma cruzi and human ribosomal proteins (molecular mimicry), as well as by advances in the knowledge of the structure of $\beta$-adrenergic receptors, used as antigens to screen for specific anti- $\beta$-adrenergic antibodies in chronic Chagas cardiomyopathy (CCC). ${ }^{4,5}$

Köerbele ${ }^{6}$ advocates that CCC is essentially neurogenic, while most authors note it is characterized by irreversible

Mailing Address: Delma Cunha

Av. Marques de Paraná, 303. Postal Code: 24220-900, Niterói, RJ - Brazil.

E-mail: delma_cunha@yahoo.com.br 
damage caused by the presence of autoantibodies., ${ }^{78}$ Recent studies have called into question the primary nature of autonomic nervous system abnormalities. Endomyocardial biopsies show continuous and progressive destruction of myocardial fibers with cardiac remodeling, as well as the presence of inflammatory and neuronal mediators in Chagas-related HF and HF of other etiologies..$^{9-11}$

The extent of myocardial damage leads to progressive ventricular dilatation with impairment of cardiac receptors and consequent autonomic dysfunction, which can predate the onset of ventricular dysfunction and occur at all stages of the disease. ${ }^{12-14}$

Anti- $\beta 1$ and anti-M2 antibodies detected early in the natural history of the disease seem to exert effects on cardiac electrogenesis through an agonistic action similar to that of adrenaline and acetylcholine, respectively. The various forms of Chagas heart disease cannot be distinguished by high serum levels of these antibodies, nor by markers of left ventricular function..$^{15-19}$

In heart failure (HF) of other etiologies, the presence of anti- $\beta 1$ autoantibodies causes prolonged activation of these cardiac receptors, inducing cell dysfunction, arrhythmias, and apoptosis ${ }^{12,13,18,19,20}$, but in $\mathrm{CD}$, some patients with CCC exhibit low levels of norepinephrine, unlike those with HF in the same functional class but of non-Chagas etiologies. ${ }^{21,22}$

Agonists for receptors coupled pleiotropically to multiple cell signaling pathways may preferentially signal some pathways over others, i.e., display bias towards certain signals. The agonist-like and allosteric effects of autoantibodies and autonomic modulation in $\mathrm{CD}$ warrant further investigation.

Within this context, the present study investigated the association of high titers of anti- $\beta 1$ and anti-M2 antibodies in CCC with autonomic dysfunction as assessed by heart rate variability (HRV) and the behavior of the ratepressure product (RPP) during cardiopulmonary exercise testing (CPET).

\section{Methods}

This was a cross-sectional study of 64 patients with CCC recruited from the outpatient cardiomyopathy clinic at the Instituto Nacional de Cardiologia (INC). This convenience sample was followed for a period of 3 years and 8 months, and is part of an extensive database created as part of a doctoral research project. ${ }^{23-24}$
The study sample was approved by the INC Research Ethics Committee, and all patients read and signed an informed consent form.

Inclusion criteria were age over 18 years and positive serology by two methods (hemagglutination and ELISA). ${ }^{25}$ Patients with pacemakers, on stem cell therapy, with insulin-dependent diabetes mellitus, stage IV hypertension, chronic kidney disease (serum creatinine $\geq 2.5 \mathrm{mg} / \mathrm{dL}$ ), anemia (hemoglobin $<9.0 \mathrm{mg} / \mathrm{dL}$ ), thyroid disease, or heart valve disease with hemodynamic compromise were excluded from the sample.

All patients received optimized clinical treatment for HF according to their NYHA functional class. Drugs with $\beta$-adrenergic action, vasodilators, diuretics, statins, angiotensin-converting enzyme inhibitors (ACEI), angiotensin receptor blockers (ARB), and antiarrhythmics were prescribed as per routine practice.

\section{Anti-cardiac receptor response}

Anti- $\beta 1$ (adrenergic) and M2 (muscarinic) receptor antibody titers were determined by means of an enzyme immunoassay (ELISA). The colorimetric response was measured by reading the optical density at a wavelength of $450 \mathrm{~nm}$ in a Molecular Devices microplate reader. ${ }^{26}$

\section{Twenty-four-hour Holter monitoring}

Patients were fitted with a Cardio Flash monitor (Cardio Sistemas Comercial e Indústria Ltda.) for evaluation of HRV. Autonomic modulation, ${ }^{27}$ expressed by HRV parameters in the time domain (milliseconds), was evaluated by specific software. Data on cardiac cycle fluctuations were obtained, and the indices related to these fluctuations were represented by the average over the whole recording period $(24 \mathrm{~h})$ and by periods of the circadian cycle of greater sympathetic (1 p.m. to 5 p.m.) and parasympathetic ( 2 a.m. to 6 a.m.) activity. The parameters of interest were NNs, mean NN, SDNN, SDANN, SDNN index, NNNs, RMSSD, and pNN50. Normal limits were based on the published literature..$^{28}$ The parameters associated with greatest risk of arrhythmic events or death are: SDANN $<40 \mathrm{~ms}$, SDNN $<50 \mathrm{~ms}$, RMSSD $<15 \mathrm{~ms}$, and $\mathrm{pNN} 50<1 \%$.

\section{Cardiopulmonary exercise test}

Exercise testing was performed on an Imbrasport ATL treadmill (Comércio de Aparelhos Eletrônicos Ltda.). Fifty-six patients underwent CPET, all on prescribed 
therapy. The ramp, Bruce, and Naughton protocols were used. Functional aerobic capacity was assessed by $V_{2}$ max and the rate-pressure product $(R P P=H R x S B P)$. The blood pressure response during the test was used as an indicator of the heart's inotropic response. Chronotropic incompetence (CI) was defined as the patient's inability to reach $85 \%$ of the maximum $H R$ predicted for their age (220 - age; $C I=$ predicted $H R$ - achieved $H R \times 100 / H R$ ). ${ }^{28-30}$

\section{Statistical analysis}

Nonparametric methods were used, as antibody titers were not normally distributed (demonstrated by rejection of the assumption of normality according to the Kolmogorov-Smirnov test). The level of significance was set at $5 \%(p<0.05)$. Statistical analysis was performed in the SAS ${ }^{\circledR}$ System software environment, version 6.11 (SAS Institute, Inc., Cary, North Carolina), and in SPSS version 17.0.

The observed data were expressed descriptively as median and interquartile range (IQR) or absolute (n) and relative $(\%)$ frequency.

The association of anti- $\beta 1$ and anti-M2 antibody titers with numerical variables was analyzed by Spearman's correlation coefficient, while the Mann-Whitney test was used for comparisons between two groups.
Multiple linear regression (MRL) was used to identify independent variables to explain anti- $\beta 1$ and anti-M2 titers. Log-transformed data were used for the titers. As shown in Figure 1, regarding anti- $\beta 1$ titers and RPP, the P-P plot does not provide any evidence contradicting the assumption of normality of residuals, and the scatterplot of residuals as a function of the standardized predicted values is quite random, validating the assumption that the residuals are independent and identically distributed. The Kolmogorov-Smirnov test did not reject the hypothesis of normality of the residuals $(p=0.71)$.

\section{Results}

\section{Sample profile}

A total of 64 patients with CCC were included. The median age was 63 years (IQR 13.6). The sample was predominantly female $(70 \%) ; 39$ patients were white $(61 \%)$, and 14 were black (22\%). All but one were migrants ( $n=63,98 \%)$, many of whom had left their states of origin (mostly Bahia, Minas Gerais, and Pernambuco) more than 30 years before. A history of poor housing conditions was found in $80 \%$ of the sample.
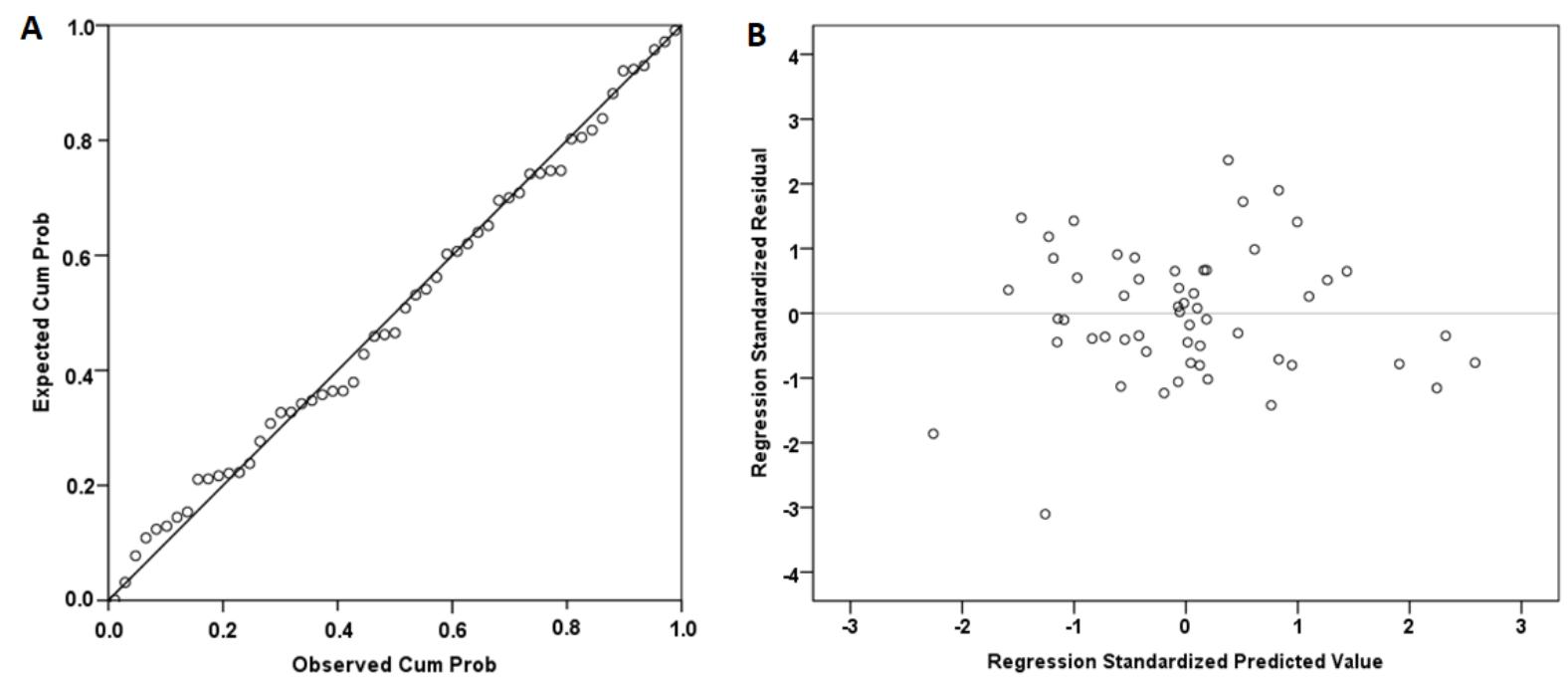

Figure 1 - Normal P-P plot and scatterplot of residuals versus predicted or observed values (anti- $\beta 1$ titers and rate-pressure product). Dependent variable "anti- $\beta 1$ titer" and independent variable "rate-pressure product", according to multiple linear regression model. A. Normal P-P plot of the standardized residual. B. Scatterplot. 
Infection occurred via the natural route in 63 patients (98\%) and via blood transfusion in 1 patient ( $2 \%)$. The social history of the sample was characterized by high rates of smoking, alcoholism, and illiteracy.

Only 1 patient had a diagnosis of diabetes. Most (78\%) were in NYHA class I or II, with a median EF of $55 \%$ by Simpson's method. (Table 1).

\section{Anti-cardiac receptor antibodies}

Anti- $\beta 1$ and anti-M2 antibody titers were evaluated in 64 patients. The median titer of anti- $\beta 1$ antibody was 0.986 (IQR 0.528), and the anti-M2 titer, 1.275 (IQR 0.625). Considering the cut-off values defined in a previous study comparing a population with and without Chagas disease $^{26}, 42.2 \%$ of patients were reactive for anti- $\beta 1$ $(>1.054)$ and $45.3 \%$ for anti-M2 antibodies (>1.297).

Table 1 - Sample profile at baseline

\begin{tabular}{|c|c|}
\hline \multirow{2}{*}{ Characteristic } & Total sample \\
\hline & $(\mathrm{N}=64)$ \\
\hline Age in years, median (IQR) & $63(13.6)$ \\
\hline Female sex, $\mathrm{n}(\%)$ & $45(70)$ \\
\hline \multicolumn{2}{|l|}{ Ethnicity, n (\%) } \\
\hline White & $39(61)$ \\
\hline Black & $11(17)$ \\
\hline Other & $14(22)$ \\
\hline $\mathrm{BMI}$ in $\mathrm{kg} / \mathrm{m}^{2}$, median (IQR) & $26(3.7)$ \\
\hline \multicolumn{2}{|l|}{ State of origin, $\mathrm{n}(\%)$} \\
\hline $\mathrm{BA}$ & $18(28)$ \\
\hline MG & $16(25)$ \\
\hline PB & $10(16)$ \\
\hline Other & $20(31)$ \\
\hline Smoking, n (\%) & $20(31)$ \\
\hline Alcoholism, n (\%) & $33(52)$ \\
\hline Educational attainment - primary education, n (\%) & $1(2)$ \\
\hline Time away from endemic area in years, median (IQR) & $30(20.3)$ \\
\hline History of living in a stucco house, $\mathrm{n}(\%)$ & $51(80)$ \\
\hline Type 2 diabetes mellitus, $\mathrm{n}(\%)$ & $1(2)$ \\
\hline Systolic blood pressure in mmHg, median (IQR) & $120(20)$ \\
\hline Heart rate in bpm, median (IQR) & $60(13.8)$ \\
\hline \multicolumn{2}{|l|}{ NYHA functional class, n (\%) } \\
\hline I & $29(45)$ \\
\hline II & $21(33)$ \\
\hline III & $14(22)$ \\
\hline Ejection fraction (Simpson's method), \%, median (IQR) & $55(21)$ \\
\hline Atrial fibrillation, $\mathrm{n}(\%)$ & $5(8)$ \\
\hline \multicolumn{2}{|l|}{ Medications for heart failure, $\mathrm{n}(\%)$} \\
\hline ACEI or ARB & $51(80)$ \\
\hline$\beta$-blocker & $24(38)$ \\
\hline Mineralocorticoid receptor antagonist & $14(22)$ \\
\hline
\end{tabular}


Twenty-four-hour Holter monitoring and cardiopulmonary exercise testing

During the study, only 43 patients underwent 24-hour Holter monitoring and 56 patients underwent CPET. Reasons for this relatively low prevalence included scheduling difficulties, referral for cell therapy and subsequent loss to follow-up at the outpatient cardiomyopathy clinic, or pacemaker placement before CPET could be performed.

On 24-hour Holter monitoring, a significant inverse correlation was observed between anti- $\beta 1$ titers and the SDNN index in the period from 2 to 6 a.m. $\left(r_{\mathrm{s}}=0.313\right.$; $p=0.041 ; \mathrm{n}=43)$; - the higher the anti- $\beta 1$ titer, the lower the expected value of the SDNN index from 2 to 6 a.m. and a significant, direct correlation between M2 titers and SDANN from 2 to 6 a.m. $\left(\mathrm{r}_{\mathrm{s}}=0.317 ; \mathrm{p}=0.039 ; \mathrm{n}=43\right)-$ the higher the anti-M2 titer, the higher the SDANN value. (Figure 2; Table 2).
On analysis of CPET results, a significant direct correlation was observed between anti- $\beta 1$ titer and the $\operatorname{RPP}\left(\mathrm{r}_{\mathrm{s}}=0.371 ; p=0.005 ; \mathrm{n}=56\right)$ : the higher the anti- $\beta 1$ titer, the higher the RPP. (Figure 2). On multiple linear regression, the RPP was the only independent variable capable of explaining anti- $\beta 1$ antibody titer at the $5 \%$ significance level $(\mathrm{p}=0.016)$. The overall explanatory power of the model, however, was low $\left(R^{2}=0.142\right)$, i.e., only $14.2 \%$ of the variability in anti- $\beta 1$ antibody titers was explained by the RPP.

The subgroup of patients with a normal chronotropic response had higher anti- $\beta 1$ titers than the subgroup with an impaired chronotropic response $(p=0.023)$. The subgroup with a normal inotropic response had higher anti-M2 titers than the subgroup with an impaired inotropic response $(p=0.044)$. Chronotropic and inotropic responses were analyzed in only 51 and 54 patients, respectively, because they

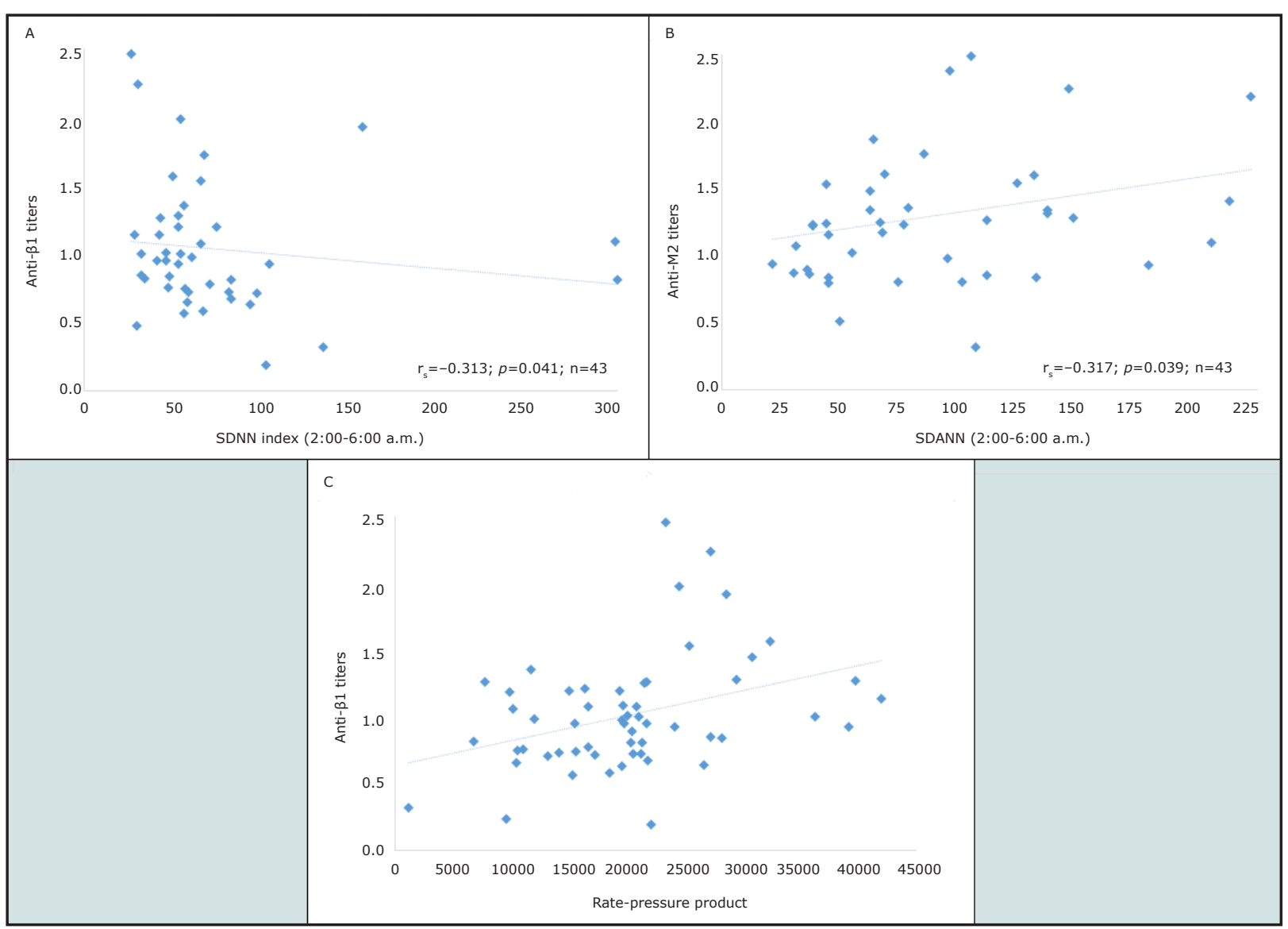

Figure 2 - Correlation between antibodies and Holter and cardiopulmonary exercise stress test variables $r_{s}$ : Spearman correlation coefficient. A. Correlation between anti- $\beta 1$ antibody titer and SDNN index on $24 h$ Holter monitoring. B. Correlation between anti-M2 antibody titer and SDANN on $24 \mathrm{~h}$ Holter monitoring. C. Correlation between anti- $\beta 1$ antibody titer and rate-pressure product on cardiopulmonary exercise test. 
were not reported by the CPET service and were not entered in the database. (Table 3).

In an exploratory analysis of antibody titers and NYHA functional class, higher anti- $\beta 1$ titers were observed in patients with better functional class (median: 1.019 in class I; 0.998 in class II; 0.884 in class III).

\section{Discussion}

Autoimmune reactions directed at $\mathrm{G}$ protein-coupled receptors and the production of anti- $\beta 1$ and anti-M2 autoantibodies acting on these receptors are often associated with changes in HRV, with a consequent increase in morbidity and mortality in patients with HF. ${ }^{31,32}$ Decreased HRV is considered an independent risk factor for arrhythmic events and all-cause mortality. Some authors have shown that a lower HRV implies a loss of cardioprotective activity of the parasympathetic system. These changes in HRV occur both in patients without functional LV abnormalities and in those with regional wall motion abnormalities and an EF lower than 50\%.12,13,16,31,33,34

Data obtained over the last three decades suggest that at least some cases of dilated cardiomyopathy (DCM) could be secondary to an autoimmune disease caused by viruses or protozoa, or even by infections that induce autoimmunity in predisposed individuals. ${ }^{13,16,19}$

Table 2 - Correlation between anti- $\beta 1$ and anti-M2 autoantibody titers and numerical variables of 24 -hour Holter monitoring

\begin{tabular}{|c|c|c|c|c|c|}
\hline \multirow{2}{*}{ Variable } & \multicolumn{3}{|c|}{ Anti- $\beta 1$ titer } & \multicolumn{2}{|c|}{ Anti-M2 titer } \\
\hline & n & $\mathbf{r}_{\mathrm{s}}$ & $p$-value & $\mathbf{r}_{\mathrm{s}}$ & $p$-value \\
\hline NNs, 2:00-6:00 a.m. & 43 & 0.067 & 0.67 & -0.177 & 0.26 \\
\hline Mean NN, 2:00-6:00 a.m. (ms) & 43 & -0.101 & 0.52 & 0.033 & 0.83 \\
\hline SDNN, 2:00-6:00 a.m. (ms) & 43 & -0.122 & 0.44 & 0.283 & 0.07 \\
\hline SDANN, 2:00-6:00 a.m. (ms) & 43 & -0.052 & 0.74 & 0.317 & 0.039 \\
\hline SDNN index, 2:00-6:00 a.m. (ms) & 43 & -0.313 & 0.041 & 0.072 & 0.65 \\
\hline NNNs, 2:00-6:00 a.m. & 43 & 0.078 & 0.62 & -0.184 & 0.24 \\
\hline RMSSD, 2:00-6:00 a.m. (ms) & 43 & -0.273 & 0.08 & -0.003 & 0.99 \\
\hline pNN50, 2:00-6:00 a.m. & 43 & -0.218 & 0.16 & 0.015 & 0.92 \\
\hline \multicolumn{6}{|c|}{$\begin{array}{l}r \text { : Spearman correlation coefficient. NNs: number of } N-N \text { intervals considered normal. Mean NN: average over all evaluated cardiac cycles. } \\
\text { SDNN: standard deviation of all N-N cycles measured during the recording. SDANN: standard deviation of the mean of the N-N intervals in all } \\
5 \text {-min segments on the record. SDNN index: mean of the standard deviation of the } N-N \text { intervals of all 5-min segments on the record. NNNs: number } \\
\text { of adjacent normal intervals measured during the recording. RMSSD: root mean square of successive differences between adjacent } N-N \text { intervals } \\
\text { during the recording. } p N N 50: \text { percentage of heart rate variability greater than } 50 \text { ms between successive normal cycles during the recording. }\end{array}$} \\
\hline
\end{tabular}

Table 3 - Comparison between anti- $\beta 1$ and anti-M2 autoantibody titers and cardiopulmonary exercise test variables

\begin{tabular}{|c|c|c|c|c|c|c|}
\hline \multirow{2}{*}{ Variable } & \multirow{2}{*}{ Category } & \multirow{2}{*}{$\mathbf{n}$} & \multicolumn{2}{|c|}{ Anti- $\beta 1$ titer } & \multicolumn{2}{|c|}{ Anti-M2 titer } \\
\hline & & & Median (IQR) & $p$-value & Median (IQR) & $p$-value \\
\hline \multirow[b]{2}{*}{ Chronotropic response } & Normal & 22 & $1.107(0.86-1.35)$ & \multirow[b]{2}{*}{0.023} & $1.270(0.99-1.58)$ & \multirow[b]{2}{*}{0.71} \\
\hline & Impaired & 29 & $0.836(0.73-1.06)$ & & $1.259(0.95-1.45)$ & \\
\hline \multirow{2}{*}{ Inotropic response } & Normal & 49 & $1.002(0.78-1.26)$ & \multirow{2}{*}{0.17} & $1.288(1.04-1.62)$ & \multirow{2}{*}{0.044} \\
\hline & Impaired & 5 & $0.758(0.63-1.11)$ & & $1.075(0.82-1.15)$ & \\
\hline
\end{tabular}


Autoantibodies that modulate the function of receptors that transduce the regulation of heart rate and contractility by the autonomic nervous system may be implicated in DCM pathogenesis. They are also present in HF of other etiologies and atrial tachyarrhythmias. Whether these autoantibodies can actually cause HF or are just an epiphenomenon in the course of disease, however, remains unknown. ${ }^{35}$

In the last decade, humoral autoimmunity against $\beta 1$ adrenergic and cholinergic receptors has come to be considered one of the probable causes of chronic HF. Therapeutic concepts have been directed towards this pathogenic process, and have shown promise in the treatment of end-stage DCM. ${ }^{10,24}$

In $C D$, evidence suggests that the continuous action of both anti- $\beta 1$ and anti-M2 autoantibodies is implicated in Chagas cardiomyopathy. Studies in rodents subjected to immunization with peptides representing the sequence of the second extracellular loop of the $\beta 1$ adrenergic receptor developed left ventricular dilatation and dysfunction, with consistent evidence of chronic stimulation and desensitization of $\beta 1$ adrenoceptor signaling, effects that were reversible upon removal of the antibodies. These studies support the hypothesis that $\beta 1$ adrenoceptor $G$ protein-coupled autoantibodies are a decisive cofactor in chronic HF. ${ }^{36,37}$

The present study showed that increased anti- $\beta 1$ and anti-M2 receptor antibody titers seem to alter nighttime HRV (2:00 to 6:00 a.m.) and exert modulating effects on membrane receptors. A decrease in sympathetic activity was observed during this period in patients with high anti- $\beta 1$ antibodies, paradoxically to their expected agonist effect. The higher the anti- $\beta 1$ antibody titer, the lower the SDNN (a marker of sympathetic activity), and the higher the anti-M2 titer, the greater the SDANN, which also reflects sympathetic activity. These changes occurred at night, where an exacerbation of parasympathetic activity could be a relevant trigger in precipitating atrioventricular blocks, symptomatic bradycardia, and syncope.

Considering that both anti- $\beta 1$ and anti-M2 antibodies behave as allosteric modulators via signal transduction, in settings where sympathetic activity is exacerbated or the parasympathetic activity is blunted, they would act in a modulatory manner to maintain overall balance. The youngest patient in this study was 33 years old and had high titers of anti- $\beta 1$ antibodies, while the oldest was 87 and had high concentrations of both anti- $\beta 1$ and anti-M2 antibodies.
These antibodies seem to exert both an inhibitory and a stimulating effect on muscarinic or adrenergic receptors. Whether these effects play any role in a protective response against nighttime tachyarrhythmias and/or bradyarrhythmias through signal transduction remains unclear.

Classically, the stimulation of adrenergic receptors consists of a signaling cascade involving the $G_{s}$ (stimulatory) protein and activation of adenylyl cyclase, which is accompanied by an increase in cyclic AMP (cAMP) and PKA (cAMP-dependent protein kinase). ${ }^{38}$

Constant stimulation of $\beta 1$ adrenergic receptors alters the $\mathrm{Ca}^{2+}$-dependent PKA signaling pathway and regulates the $\mathrm{Ca}^{2+}$ current by mechanisms involving $\mathrm{Ca}^{2+} / \mathrm{calmodulin}$ dependent protein kinase II, leading to myocyte apoptosis and changes in cardiac adaptation mechanisms, which in turn lead to ventricular remodeling. ${ }^{20,23}$

Some proteins have allosteric and modulating properties and bind to their substrates non-competitively, with the ability to produce a conformational change in protein structure. Proteins are dynamic compounds, and have multiple functional or conformational states. A signaling molecule interacts with its receptor and activates cellular mechanisms, producing a second signal or change in activity in the cellular protein, altering the metabolic activity of the target cell. ${ }^{16,38}$

In HF of other etiologies, the presence of anti- $\beta 1$ antibodies is associated with greater morbidity, and some authors believe that these antibodies can be considered predictors of mortality. The CIBIS-ELD study used a novel ELISA approach to investigate the relationship between anti- $\beta 1$ antibodies in a cohort of HF patients and found that patients with an ejection fraction $<50 \%$ and a diastolic diameter $>55 \mathrm{~mm}$ had higher heart rates and significantly higher anti- $\beta 1$ antibody titers. ${ }^{39}$

Beta-blocker therapy, despite being highly effective, is insufficient to prevent clinical deterioration in the presence of anti- $\beta 1$ autoantibodies. ${ }^{40}$ In $C D$, there is evidence showing that patients with CCC have low levels of norepinephrine, unlike their counterparts at the same functional class but with HF of non-Chagas etiologies. ${ }^{21}$

This study also assessed whether anti- $\beta 1$ and anti-M2 antibodies would have influenced physiological responses during exercise in patients with $\mathrm{CD}$.

Some CPET variables are markers of severity, including HR reduction in the first minute of recovery and a decline in blood pressure during exercise. 
However, these parameters were not associated with the presence of anti- $\beta 1$ or anti-M2 antibodies. It is well known that initial exertion-induced tachycardia depends on suppression of vagal activity, while further increases in HR depend on autonomic (specifically, sympathetic) increments according to exercise intensity. ${ }^{30}$

In this study, a normal chronotropic response and RPP were found to be associated with high anti- $\beta 1$ titers. Patients with a normal inotropic response had high anti-M2 titers. The agonistic action of these antibodies on $\beta$ adrenergic receptors explains the increase in HR and blood pressure. The increase in RPP was attributed to the additional positive allosteric modulating action of the anti- $\beta 1$ adrenergic antibody during exercise, acting as a ligand that modifies the action of an orthosteric agonist, endogenous activator, or antagonist by binding to the allosteric site of the receptor. ${ }^{38}$

Higher anti-M2 titers reflect a modulating action or interaction with other signaling pathways (signal transduction), which stimulate sympathetic action in the heart and other systems that participate in the ANS signaling cascade. ${ }^{38}$ Anti-M2 antibodies appear to exert both negative and positive allosteric modulating actions. Both anti- $\beta 1$ and anti-M2 antibodies modulate the cascade of adaptive ANS responses during exercise. ${ }^{41,42}$

Considering the findings of previous studies on autoantibodies, ${ }^{37}$ at least three distinct effects of these antibodies on their respective receptors must be considered: they modulate binding of true ligands; they activate various effector pathways; and they modulate the disposition of the receptor and simultaneous binding to the receptor. However, how autoantibodies cause changes in receptor activity and how this relates to the pathogenesis and severity of CCC remains unclear.

Whether the presence of circulating antibodies has any role in the clinical outcome of patients with CCC is still an open matter; future clinical trials are needed to assess the prognostic nature of these antibodies. Some authors have shown that immune cross-reactivity is not always harmful, and a balanced parasite/host relationship may exist, allowing the disease to remain clinically silent for many years. ${ }^{11,19}$

In Chagas' heart disease, myocardial remodeling seems to be related to etiopathogenic mechanisms linked to neuronal activation. The prognosis is worse compared to that of other cardiomyopathies, with a disturbingly high incidence of sudden death secondary to arrhythmias, and current therapeutic approaches are based on results obtained in heart diseases of another etiologies. ${ }^{12,13,16}$

Including measurement of anti- $\beta 1$ and anti-M2 autoantibody in the routine workup of patients with CD, plus exercise testing and 24-hour Holter monitoring, would create a panel for assessment of the whole spectrum of HRV behavior and its relationship with autoantibodies in the long-term follow-up of these patients.

This study has some limitations, including: 1) the absence of a control group for comparison of findings; 2) the fact that the sample was not separated into groups by NYHA functional class for analysis of HRV and autoantibody behavior according to the degree of cardiac remodeling; 3 ) the fact that autoantibody titers were not compared with those measured in cardiomyopathies of other etiologies; 4 ) the lack of functional testing of anti- $\beta 1$ and anti-M2 antibodies (in a Langendorff preparation) from the serum of these patients for comparison with HRV behavior and measurement of a potential active role of these antibodies in ANS modulation, since functionally active antibodies can modulate vagal action even in the absence of structural heart disease. ${ }^{43-45}$ Finally, since autoantibodies are part of the immune background of heart disease, 5) the lack of tools and diagnostic criteria specific for CCC makes it difficult to interpret the data and monitor the natural history of these patients.

\section{Conclusion}

The data presented herein show that anti- $\beta 1$ and anti-M2 autoantibodies seem to exert a modulating effect on the autonomic nervous system, altering nighttime measures of HRV (SDNN and SDANN). There was an inverse association between anti- $\beta 1$ antibodies and sympathetic activity, and a direct association between anti-M2 and sympathetic activity during this period.

The rate-pressure product correlated significantly with anti- $\beta 1$ antibody titers, although as an independent variable $(5 \%)$, the association was weak.

\section{Acknowledgment}

The authors would like to thank the cardiography team at Instituto Nacional de Cardiologia and, particularly, 
the Biology and Molecular Diagnosis laboratory of the same Institute.

\section{Author contributions}

Conception and design of the research: Cunha DM, Cunha AB. Acquisition of data: Cunha DM, Cunha AB. Analysis and interpretation of the data: Cunha DM. Statistical analysis: Noé R. Writing of the manuscript: Cunha DM, Tzirulnik PC. Critical revision of the manuscript for intellectual content: Cunha AB, Cunha DM.

\section{Potential Conflict of Interest}

No potential conflict of interest relevant to this article was reported.

\section{References}

1. Brasil, Ministério da Saúde. Secretaria de Vigilância em Saúde. Boletim Epidemiológico. Série histórica de 2000 à 2013; 2015;46(21) ISSN 2358-945046.

2. Secretaria de Vigilância em Saúde. Boletim epidemiológico 36. Panorama da Doença de Chagas no Brasil. Brasilia; 2019.

3. Moncayo A, Ortiz Yanine MI. Centennial review. An update on Chagas disease (human American trypanosomiasis). Ann Trop Med Parasitol. 2006;100(8):663-7.

4. Levin MJ, Mesri E, Benarous R, Levitus G,Schijman A, Levy-Yeyati P, et al. Identification of major Trypanosoma cruzi antigenic determination in Chronic Chagas Heart Disease. Am J Trop Med Hyg.1989;41(5):530-8.

5. Schijman AC, Dusetti NJ, Vasquez MP, Lafon S, Levy -Yeyati P, Levin MJ. Nucleotide cDNA and complete deduced amino acid sequence of a trypanosoma cruzi P ribosomal protein (P-JL\%). Nucleic Acids Research. 1990;18(11):3399.

6. Köeberle F. Pathogenesis of Chagas' disease. In: Ciba Foundation Symposium. Amsterdam: Associated Scientific; 1974. p.137-58.

7. Tafuri WL, Brener Z. Lesões do sistema nervoso autônomo do camundongo albino na Trypanossomíase experimental na fase aguda. O Hospital. 1996; 69:371-83.

8. Andrade SG, Andrade ZA. Doença de Chagas e alterações neuronais no plexo de Auenbach (Estudo experimental em camundongos). Rev Inst Med Trop. 1966; 8(5):219-24.

9. Bocchi EA, Bestetti RB, Scanavacca MI, Cunha Neto E, Issa VS. Chronic Chagas Heart Disease Management: From Etiology to Cardiomyopathy Treatment. J Am Coll Cardiol. 2017 Sep 19;70(12):1510-24. doi: 10.1016/j. jacc.2017.08.004.

10. Herda LR, Felix SB, Boege F. Drug-like actions of autoantibodies against receptors of the autonomous nervous system and their impact on human heart function. Br J Pharmacol. 2012 Jun;166(3):847-57. doi: 10.1111/j.14765381.2012.01828.x.

11. Cunha-Neto E, Chevillard C. Chagas disease cardiomyopathy: immunopathology and genetics. Mediators Inflamm. 2014;2014:683230. doi: 10.1155/2014/683230.

12. Düngen HD, Dordevic A, Felix SB, Pieske B, Voors AA, McMurray JJV,et al. $\beta_{1}$-Adrenoreceptor Autoantibodies in Heart Failure: Physiology and Therapeutic Implications. Circ Heart Fail. 2020 Jan;13(1):e006155. doi: 10.1161/CIRCHEARTFAILURE.119.006155.

\section{Sources of Funding}

There were no external funding sources for this study.

\section{Study Association}

This study is not associated with any thesis or dissertation work.

\section{Ethics approval and consent to participate}

This study was approved by the Ethics Committee of the Instituto Nacional de Cardiologia under the protocol number 0153/05.06.07. All the procedures in this study were in accordance with the 1975 Helsinki Declaration, updated in 2013. Informed consent was obtained from all participants included in the study.

13. SchwartzPJ, La Rovere MT, DeFerrari GM, Mann DL. Autonomic modulation for the management of patients with chronic heart failure. Circ Heart Fail. 2015 May;8(3):619-28. doi: 10.1161/CIRCHEARTFAILURE.114.001964.

14. Ribeiro AL, Moraes RS, Ribeiro JP, Ferlin EL, Torres RM, Oliveira E, Rocha MO. Parasympathetic dysautonomia preceds left ventricular systolic dysfunction in Chagas' disease. Am Heart J. 2001; 141(2):260-5.

15. Costa PCS. Desempenho Cardíaco na Cardiopatia Chagásica Crônica: Modulação das funções mecânica e elétrica cardíacas por autoanticorpos contra receptores acoplados a proteína G.Tese. Rio de Janeiro: Universidade Federal do Rio de Janeiro;2006.

16. Terhoch CB, Moreira HF, Ayub-Ferreira SM,Souza GEC, Salemi VMC, Chizzola PR, et al. Clinical findings and prognosis of patients hospitalized for acute decompensated heart failure: Analysis of the influence of Chagas etiology and ventricular function. Plos Negl Trop Dis. 2018 Feb;12(2):e0006207. DOI: 10.1371/journal.pntd.0006207.

17. Hernandez CC, Barcellos LC, Gimenez LE, Cabarcas RA, Garcia S, Pedrosa RC, et al. Human chagasic IgGs bind to cardiac muscarinic receptors and impair L-type $\mathrm{Ca}^{2+}$ currents. Cardiovasc Res.. 2003;58(1):55-65.

18. Hernandez CC, Nascimento JH, Chaves HA, Costa PC, Masuda MO, Kurtenbach E, et al. Autoantibodies Enhance Agonist Action and Binding to Cardiac Muscarinic Receptors in Chronic Chagas Disease. J Recept Signal Transduct Res. 2008; 28(4):375-40.

19. Neto MA, Rascado RR, Bendhack LM. Receptores $\beta$ adrenérgicos no Sistema Cardiovascular. Medicina (Ribeirão Preto). 2006; 39(1):3-12.

20. Liang CS, Mao W, Liu J. Pro apoptotic effects of anti- $\beta 1$ adrenergic receptor antibodies in cultured rat cardiomyocytes: Actions on endoplasmic reticulum and the prosurvival P13K-AKt pathway. Autoimmunity. 2008; 41(6):434-41.

21. Cunha AB, Cunha DM, Pedrosa RC, Flammini F, Silva AJ, Saad EA Kopiler DA. Norepinephrine and heart rate variability: a marker of dysautonomia in chronic Chagas cardiopathy. Rev Port Cardiol. 2003 Jan;22(1):29-52.

22. Cunha AB. A Doença de Chagas e o Envolvimento do Sistema Nervoso Autônomo. Rev Port Cardiol.2003;22(6):813-24.

23. Calil I, Tinelli RA, Andrade Vicente WV,Rodrigues AJ, Barbosa Evora PR The Concept of crosstalk and its implication for cardiovascular function and disease. Arq Bras Cardiol.2007; 88(1):e26-e31. 
24. Kenakin T. Signaling bias in drug discovery. Expert Opin Drug Discov. 2017 Apr;12(4):321-33. doi: 10.1080/17460441.2017.1297417.

25. Fuchs AP, Fioratti VL, Mello VA, Boainain E. Diagnóstico sorológico na doença de Chagas: estudo comparativo de diferentes técnicas. Rev Inst Med Trop S Paulo. 1980; 22(5): 242-5.

26. Cunha DM. O estudo dos autoanticorpos antirreceptores $\beta 1$ e Anti-M2 na cardiopatia chagásica crônica. Tese. Rio de Janeiro: IPEC/FIOCRUZ; 2012.

27. Task Force of the European Society of Cardiology and the North American Society of Pacing and Electrophysiology. Heart rate variability: standards of measurements, physiological interpretation and clinical use. Circulation. 1996; 93(5):1043-65

28. Cole CR, Blackstone EH, Pashkow FJ, Snader CE, Lauer MS. Heart rate recovery immediately after exercise as a predictor of mortality. N Engl J Med. 1999. 341(18):1351-7.

29. Borg GA. Perceived exercion: a note on history and methods. Med Sci Sports.1977;5(2):90-3

30. Alonso DO, Forjaz CLM, Resende LO, Braga AM, Barreto ACP, Negrão $\mathrm{CE}$, et al. Comportamento da frequência cardíaca e da sua variabilidade durante as diferentes fases do exercício físico progressivo máximo. Arq Bras Cardiol. 1998; 71(6):787-92.

31. Ribeiro ALP, Lombardi F, Souza MR, Lins Barros MV, Porta A, Val Barros $\mathrm{VC}$, et al. Power - low behavior of heart rate variabilty in Chagas'disease. Am J Cardiol. 2002; 89(4):414-8.

32. Bigger JT, Fleiss JL, Steinman RC, Rolnizky LM, Kleiger RE, Rottman JN . Correlations among time and frequency domain measures of heart period variability two weks after acute myocardial infarction.Am J Cardiol.1992;69(9):891-8.

33. Bigger JT, Fleiss JL, Steinmam RC, Rolnitzky LM, Kleiger RE, Rottman JN. Frequency domain measures of heart period variability and mortality after myocardial infarction. Circulation. 1992;85(1):164-71.

34. Bigger Jt, FleissJL, Steinmam RC, Rolnitzky LM, Schneider WJ, Stein PK. RR variability in healthy, middle age persons compared with pacients with chronic coronary heart disease or recent acute myocardial infarction. Circulation. 1995;91(7):1936-43.

35. Junqueira Jr LF. Insights sobre o significado clínico e funcional da disfunção autonômica cardíaca na doença de Chagas. Rev Soc Bras Med Trop.2012;45(2):243-52. https://doi.org/10.1590/S0037-86822012000200020.
36. Boivin-Jahns V, Jahns R, Boege F. Relevant effects of beta -adrenoceptor $_{1}$ autoantibodies in chronic heart failure. Front Biosc (Landmark Ed). 2018 Jun 1;23:2146-56. PMID: 29772551

37. Wölfel A, Sättele M, Zechmeister C, Nikolaev VO, Lohse MJ, Boege F, et al. Unmasking features of the auto-epitope essential for $\beta_{1}$-adrenoceptor activation by autoantibodies in chronic heart failure. ESC Heart Fail. 2020 Aug;7(4):1830-41. doi: 10.1002/ehf2.12747.

38. Taira CA, Carranza A, Mayer M, Di Verniero C, Opezzo JAW. Therapeutic implications of beta-adrenergic receptor pharmacodynamic properties. Curr Clin Pharmacol. 2008;3(3):174-84.

39. Trippel TD, Mueller DN, Obradovic D, Edelmann F, Tahirovic E, Wilck $\mathrm{N}$, et al. Anti-\$1-Adrenoreceptor auto-Antibodies in elderly heart failure patients. Front Biosci(Landmark Ed). 2019 Mar 1;24:1037-49. PMID: 30844728.

40. Düngen HD, Apostolovic S, Inkrot S, Tahirovic E, Topper A, Mehrhof F, et al. Project Multicentre Trials in the Competence Network Heart Failure: Titration to target dose of bisoprolol vs. carvedilol in elderly patients with heart failure: the CIBIS-ELD trial. Eur J Heart Fail .2011;(6):670-80. DOI: 10.1093/eurjhf/hfr020

41. Benchimol-Barbosa PR. Comments on the article by Ribeiro et al. 'Enhanced parasympathetic activity in Chagas' disease still stands in need of proof': definitions and biases. Int J Cardiol. 2011;146(1):88-90. doi:10.1016/j.ijcard.2009.09.560

42. Neves BC, Bacilio ML, Bermela L, Salmen S, Peterson DL, Donis $\mathrm{JH}$, et al. Muscaric antibodies and heart rate responses to dynamic exercise and to the valsava maneuver in chronic Chagas. Rev Inst Med Trop.2013;55(1):31-7.

43. Oliveira SF, Pedrosa RC, Nascimento JH, Campos de Carvalho AC, Masuda MO. Sera from chronic chagasic patients with complex cardiac arrhythmias depress electrogenesis and conduction in isolated rabbit hearts.Circulation.1997;96(6):2031-7.

44. Thiers CA. Disfunção autonômica e sua associação com anticorpos funcionalmente ativos contra receptores acoplados a proteína-G em pacientes com doença de Chagas crônica e função sistólica preservada. Tese. Rio de Janeiro. UFRJ / ICES/ Faculdade de Medicina;2012.

45. Nascimento EM, Nascimento JH, Medei EH, Pedrosa RC. Autonomic dysfunction and anti-M2 and anti- $\beta 1$ receptor antibodies in Chagas disease patients. Arq Bras Cardiol. 2012 Aug; 99(2):732-9. doi: 10.1590/ s0066-782x2012005000067. 